\title{
Efficacy and Economics of Management Strategies to Control Anthracnose Fruit Rot in Processing Tomatoes in the Midwest
}

\author{
J. M. Byrne, Former Graduate Research Assistant, and M. K. Hausbeck, Assistant Professor, Department of Bot- \\ any and Plant Pathology, Michigan State University, East Lansing 48824; and R. X. Latin, Professor, Purdue Uni- \\ versity, West Lafayette, IN 47907-1155
}

\begin{abstract}
Byrne, J. M., Hausbeck, M. K., and Latin, R. X. 1997. Efficacy and economics of management strategies to control anthracnose fruit rot in processing tomatoes in the Midwest. Plant Dis. $81: 1167-1172$.

Anthracnose (Colletotrichum coccodes) is the major fungal disease affecting processing tomato fruit in the midwestern United States. Currently available disease management strategies evaluated for controlling anthracnose fruit rot (AFR) on processing tomatoes include genetic resistance and the fungicide chlorothalonil applied according to conventional schedules or a diseaseforecasting system (Tom-Cast). Experimental field plots were established in West Lafayette, Indiana, and East Lansing, Michigan, in 1993 to 1995. Chlorothalonil was applied every 7, 10, or 14 days or according to Tom-Cast with a threshold of 20 disease severity values, and was not applied to the control. In Michigan, Phytophthora infestans (1993) and C. coccodes (1993 to 1994) caused $91.8 \%$ (1993) and 30.7\% (1994) fruit rot in the unsprayed plot. In Indiana, $C$. coccodes caused 69.8\% (1993) and 39.0\% (1994) AFR in the unsprayed plot. In 1995, Ohio 8245 (Michigan and Indiana), considered to be less prone to anthracnose, and Ohio 7814 were integrated into the conventional and Tom-Cast-prompted spray programs. Cultivar did not affect the incidence of AFR or foliar blight caused by Septoria lycopersici and Alternaria solani in either location. In 1993 and 1994, chlorothalonil applied at 10-day intervals in Indiana resulted in the highest benefit per hectare (BPH) and return per fungicide dollar (RPFD). In 1995, the highest BPH and RPFD resulted from chlorothalonil applied every 14 days to Ohio 8245 (Michigan). Chlorothalonil applied according to the Tom-Cast program resulted in a level of AFR that was generally not statistically different from the 7-day treatment but was high enough to result in crop rejection and high economic loss in 2 of the 3 years the study was conducted. Based on data from this study, it is not commercially feasible to grow processing tomatoes in Michigan and Indiana without chlorothalonil to protect against AFR even when a resistant cultivar is used.
\end{abstract}

Additional keywords: AUDPC, FAST, fruit quality, fungicide residue, integrated pest management

Anthracnose fruit rot (AFR) caused by Colletotrichum coccodes (Wallr.) Hughes is considered the most serious ripe-fruit rot of processing tomatoes in the north central production region. Without control, fruit rot incidence can be as high as $70 \%$ (20); even repeated fungicide applications can result in 5 to $15 \%$ fruit rot incidence (31). Symptoms appear only on ripe or senescent fruit and include slightly sunken circular lesions that may expand and coalesce, resulting in extensive fruit rot $(6,17,31)$. Anthracnose fruit rot is favored by the processing tomato production system that includes a delayed harvest of ripe fruit to allow optimum timing for once-over ma-

Corresponding author: J. M. Byrne
E-mail: byrnejm@pilot.msu.edu

Portion of the first author's M.S. thesis submitted to Michigan State University.

Accepted for publication 7 July 1997.

Publication no. D-1997-0820-01R

(C) 1997 The American Phytopathological Society chine harvesting. In contrast, fresh market tomatoes are picked in multiple harvests at the breaker stage (first appearance of color) and are shipped and typically consumed before latent $C$. coccodes infections develop.

Currently, fungicides are essential for processing tomato production and are applied on nearly $100 \%$ of the tomato hectarage in the north central production region (28). Most growers initiate fungicide sprays when fruit first set and apply subsequent sprays every 4 to 14 days even if there is no disease risk, resulting in 12 or more applications each season. Although fungicides may not affect total yield $(2,3,19,20,27)$, they may significantly affect fruit quality by decreasing fruit rot caused by $C$. coccodes, Alternaria solani (Ellis \& G. Martin) Sorauer, and Phytophthora infestans (Mont.) de Bary $(2,15,16,20)$. Fruit quality is especially important in processing tomato production because of the stringent requirements imposed by the Food and Drug Administration and processors regarding acceptable mold counts and fruit rot incidence $(5,13,14)$.
Recent concerns about fungicide residues on food have significantly affected midwestern tomato production, which has received attention because of heavy fungicidal use in disease control programs (23). Disease management strategies that reduce fungicide use without increasing diseaserelated losses have been implemented successfully in the Midwest and Ontario (13). A forecast system for tomato early blight caused by A. solani (FAST) was developed by Madden et al. (21) and effectively identifies periods when the disease is favored. When fungicides are sprayed according to the model, there are typically fewer applications than if a weekly spray schedule is used $(21,24)$. Pitblado $(25,26)$ simplified FAST and determined that a modified disease forecaster (Tom-Cast) was effective against several tomato foliar and fruit diseases including early blight, AFR, and Septoria (Septoria lycopersici (Speg.)) leaf spot.

Chlorothalonil is the sole fungicide used in Tom-Cast-prompted and conventional spray programs for processing tomatoes in the Midwest. The processing tomato industry will not accept produce treated with ethylenebisdithiocarbamate (EBDC) fungicides because of adverse publicity (3). Other labeled fungicides such as fixed copper do not offer adequate protection against high disease pressure $(15,32,33)$. Reliance upon chlorothalonil renders tomato production in the Midwest vulnerable, and loss of the chlorothalonil registration could collapse the industry (22).

Tomato cultivars with various amounts of resistance to AFR are commercially available (34). Barksdale and Stoner (1) found the AFR resistance in their tomato breeding lines was equal to four fungicide applications when compared with two standard susceptible cultivars. AFR resistance may be used in combination with a disease forecasting system to maximize fungicide use. Fulling et al. (12) estimated optimum action thresholds for cultivars with various levels of AFR resistance by using a theoretical level of acceptable fruit rot and the slope of the percentage of diseased fruit regressed on actual thresholds used. Results indicated that when resistant cultivars were used with the Tom-Cast program, action thresholds could be modified and fungicides applied three to four fewer times per year compared with using susceptible cultivars. We are interested in 
implementing these management tools in an attempt to reduce fungicide use while maintaining the economic viability of processing tomato production in the Midwest.

The objective of this research was to assess the efficacy and economics of genetic resistance and chlorothalonil applied according to conventional schedules or TomCast for AFR control in processing tomato.

\section{MATERIALS AND METHODS}

Plot establishment. Research plots were established in a sandy loam soil at the Botany and Plant Pathology Research Farm in East Lansing, Michigan, and in an Ockley silt loam at the O'Neall Horticultural Research Center in West Lafayette, Indiana. The experimental sites were prepared and fertilized, and weeds were managed according to standard commercial practices (29). Overhead irrigation was applied as needed. In 1993, the Indiana (IN) site had a recent history of tomato production and associated AFR and foliar diseases. The 1993 Michigan (MI) plot and 1994 MI and IN plots were established on sites never planted to tomatoes. Six-weekold Ohio 7814 tomato transplants grown in 288-cell flats were planted at $0.45-\mathrm{m}$ spacing in rows $1.82 \mathrm{~m}$ apart on 1 (IN) and 11 (MI) June 1993 and 3 (IN) and 27 (MI) June 1994. In 1993 and 1994, a randomized complete block design was used with six replicates, each consisting of a single row containing 19 plants. Treatment rows were alternated with buffer rows of Ohio 8245 (1993 to 1994).

In 1995, Ohio 7814 and Ohio 8245 transplants were planted on 30 May (IN) and 1 June (MI). Using a resistance index, Fulling et al. (12) determined that Ohio 8245 is more resistant to AFR than Ohio 7814. The MI site had previously been planted to alfalfa for 2 years following 12 years of tomato production. The IN site had previously been planted to soybeans. Plots were arranged in a split-plot design with cultivar as the main plot and fungicide treatment as the subplot.

The experimental plots (1993 to 1995) in IN were left to natural inoculation. In Michigan (1993 to 1995), treatment rows were inoculated with $C$. coccodes-infested millet seed to increase disease pressure. Sterile millet seed $\left(400 \mathrm{~cm}^{3}\right)$ combined with distilled water $(160 \mathrm{ml})$ was infested with six 1-cm disks of 10- to 14-day-old $C$. coccodes grown on medium containing V8 juice (30\%) and agar (2\%) (Difco Laboratories, Detroit, MI). Inoculum was incubated in 1-liter flasks at $20^{\circ} \mathrm{C}$ and a $12-\mathrm{h}$ photoperiod for 3 weeks. Infested millet seed was dried and stored in paper bags until it was spread $\left(400 \mathrm{~cm}^{3}\right.$ per $21.9 \mathrm{~m}$ of row) alongside all treatment rows shortly after transplanting.

Chlorothalonil treatments. Chlorothalonil (Bravo 720 at $2.53 \mathrm{~kg}$ a.i./ha) was applied every 7,10 , or 14 days or accord- ing to Tom-Cast and was not applied to the control. At the MI site, fungicide applications were made with a $\mathrm{CO}_{2}$ backpack sprayer that operated at $344.8 \mathrm{kPa}$ and delivered 344 liters/ha through two XR Tee-Jet 8004 flat-fan nozzles. At the IN site, fungicides were applied with a handheld boom sprayer with four Tee-Jet flatfan nozzles (80015 VS, 1993 and 1994, and 8003VS, 1995) spaced $45.7 \mathrm{~cm}$ apart. The sprayer was calibrated to deliver 242.2 liters/ha at a nozzle pressure of $275.8 \mathrm{kPa}$ (1993 and 1994) and 193.1 (1995) $\mathrm{kPa}$. Sprays were initiated on 14 (IN) and 28 (MI) July 1993, 8 (IN) July and 3 (MI) August 1994, and 6 (IN) and 25 (MI) July 1995 when the crown fruit were one-third of the estimated size.

According to the Tom-Cast model, a disease forecasting system, the first spray was applied on 11 July or earlier if 28 days had elapsed since transplanting and if the disease severity values (DSV) had a cumulative value of 35 for tomatoes planted before 23 May and 45 for those planted after 23 May $(13,26)$. Subsequent sprays were applied after the accumulation of 20 DSVs since the last fungicide application $(8,16,18,26)$. Hourly averages of leaf wetness and temperature data were collected with digital recorders (Omnidata DP223, Omnidata International, Inc., Logan, Utah [MI] and WeatherLog, RainWise, Inc., Bar Harbor, ME [IN]).

Treatments applied according to TomCast were initiated on 11 (MI) July 1993, 11 (MI) and 8 (IN) July 1994, and 11 (MI) and 6 (IN) July 1995; Tom-Cast was not included in 1993 in Indiana. In 1993 and 1994 (MI and IN) and 1995 (MI), eight, six, and four chlorothalonil sprays were applied for the 7-, 10-, and 14-day-interval treatments, respectively. In 1995 at the IN site, 10, 7, and 5 chlorothalonil sprays were applied for the 7-, 10-, and 14-dayinterval treatments, respectively. Tom-Cast advised four (MI) sprays in 1993, three (MI) and five (IN) sprays in 1994, and six (MI) and seven (IN) sprays in 1995.

Assessment of fruit rot. Fruit were hand-harvested from the eight innermost plants of the treatment row when approximately $75 \%$ were ripe. Since late blight caused by $P$. infestans had completely defoliated the unsprayed plots at the MI site by 13 September 1993, fruit in this treatment ripened earlier than those of the other treatments and were harvested on 17 September. All other treatments were harvested on 23 September. In 1994, plots at the MI site were harvested on 4 October. Plots at the IN site were harvested on 14 September 1993 and 9 September 1994. In 1995 (MI), plots were harvested when the later-ripening Ohio 8245 was ripe (5 October). In 1995 (IN), harvests were made on 2 and 11 September for cultivars Ohio 7814 and Ohio 8245, respectively. A randomly collected sample of 100 ripe fruit from each plot was evaluated for symp- toms of fruit infection, and the percentage of diseased fruit was analyzed by analysis of variance (ANOVA) with a protocol of the Statistical Analysis System (SAS Institute, Inc., Cary, NC). Yield was not measured in this study since previous research indicated that fungicide programs would not be expected to influence yield $(2,3,19,27)$.

Assessment of foliar disease. Foliar disease caused by A. solani, S. lycopersici, and $P$. infestans was assessed visually (0 to $100 \%$ ) each year at each site. Area under the disease progress curve (AUDPC) was calculated to express the cumulative incidence of leaf infection occurring over a 39day (IN) and 13-day (MI) period in 1993, a 48-day (IN) and 21-day (MI) period in 1994, and a 26-day (IN) and 36-day (MI) period in 1995 according to the method of Shaner and Finney (30). Data (AUDPC) were analyzed by ANOVA with a protocol of the Statistical Analysis System. Treatment means were compared with the LSD $(P=0.05)$ test.

Economic benefit of management programs. Using a crop value of $\$ 82.60 / \mathrm{t}$, benefits assessments were determined for a crop yield of $60.8(\$ 5,025) \mathrm{t} / \mathrm{ha}$. Values were based on averages of processing tomato crop yield and price per ton for 1993 to 1995 in the Midwest (35). Assuming that the 7-day-interval treatment provided acceptable disease control, the fruit rot percentage (FRP) was determined using treatment means as the total fruit rot $(\%)$ above that observed in the 7-day-interval treatment plot. The 7-day interval is the schedule most commonly used by commercial growers. In treatments in which FRP was higher than $2.9 \%$, the value of the crop was reduced to zero to represent the loss caused by a processor's rejection of a crop with a high infection and mold-count incidence (S. Smith, Red Gold, Inc., personal communication). The total cost (TCOST) of each fungicide program was calculated by multiplying the number of applications by cost $(\$ 45.70 /$ ha per application) (9). The fungicide benefit per hectare (BPH) of the crop was determined by subtracting fungicide costs from the crop value. In treatments in which the crop had no value because the FRP $>2.9 \%$, the $\mathrm{BPH}$ is negative to represent the loss caused by fungicide expenditure in addition to the crop loss. The return per fungicide dollar (RPFD) was calculated by dividing the $\mathrm{BPH}$ by the season-long fungicide cost (TCOST) to identify programs using fungicide dollars most efficiently.

For example, if the 7-day-interval treatment resulted in 2\% AFR, $2 \%$ would be presumed acceptable control (no reduction in crop value) for our analysis. If a 10-dayinterval treatment resulted in $4 \%$ AFR, the associated FRP would be $2 \%$ and therefore acceptable for processing. The BPH $(\$ 4,659.40)$ representing the gain associated with fungicide use is determined by 
subtracting the TCOST of the fungicide program (\$365.60) from the crop value (\$5,025.00). To obtain the RPFD (\$12.74), the BPH $(\$ 4,659.40)$ is divided by the TCOST of the fungicide program (\$365.60).

\section{RESULTS}

Management of fruit rot. In Michigan during 1993, the incidence of fruit rot caused by $P$. infestans and $C$. coccodes was high $(91.8 \%)$ in the unsprayed control plot. All fungicide treatments reduced fruit rot incidence compared with the unsprayed control plot (Table 1). In the fungicidetreated plots, 9.2 to $18 \%$ of the fruit were diseased, a percentage that did not differ significantly among fungicide treatments. In 1994, the incidence of AFR was moderate, causing $30.7 \%$ diseased fruit in the unsprayed control plot (Table 1). All fungicide treatments resulted in fewer diseased fruit in comparison to the unsprayed control plot. Applications of chlorothalonil every 7 days resulted in significantly fewer diseased fruit than that in the other fungicide treatments. The 10-day-interval treatment had significantly fewer diseased fruit than the 14-day-interval and Tom-Cast treatments. There was no significant difference in the proportion of diseased fruit between the 14-day-interval and Tom-Cast treatments, despite the Tom-Cast treatment having one less fungicide application.

In Indiana during 1993, the incidence of AFR was high $(69.8 \%)$ in the unsprayed control plot (Table 1). All fungicide treatments reduced AFR in comparison to the unsprayed control. The 7- and 10-day-interval treatments resulted in fewer diseased fruit $(<10.5 \%)$ compared with the 14-dayinterval treatment $(24.3 \%)$. In 1994, the incidence of AFR was moderate $(39.0 \%)$ in the unsprayed control plot (Table 1). All fungicide treatments were equally effective in producing significantly fewer diseased fruit $(1.8$ to $9.3 \%)$ in comparison to that in the unsprayed control.

In 1995, cultivar had no significant effect on AFR in either location. Within each cultivar, all fungicide treatments significantly reduced AFR compared with the unsprayed control plots (Table 2). AFR did not differ significantly between the 7-day and Tom-Cast-prompted treatments. There were no significant differences $(P=0.05)$ in incidence of AFR among the fungicide treatments with the exception of Ohio 8245 (IN), whose 14-day treatment resulted in higher AFR than did the other fungicide treatments.

Management of foliar blight. In MI during 1993, untreated control plots were completely defoliated by late blight. Fungicide applications limited final foliar infection to $18.5,17.0,21.1$, and $34.3 \%$ for sprays applied every 7,10 , and 14 days and according to Tom-Cast, respectively. At the last assessment date in 1994, $19.2 \%$ of the foliage in the untreated control plot exhibited symptoms of Septoria leaf spot and early blight. Chlorothalonil limited final foliar infection to $4.3,6.3,6.8$, and $5.3 \%$ for sprays applied at 7,10 , and 14 days and according to Tom-Cast, respectively. According to AUDPC data, all fungicide treatments significantly reduced foliar blight in comparison to the untreated control in 1993 to 1994 (Table 1). Fungicide treatments' efficacy against foliar blight did not differ significantly.

In Indiana during 1993, symptoms caused by $S$. lycopersici and $A$. solani were present on $94 \%$ of the foliage in control plots at the last observation date. Fungicide applications limited final foliar infection to 36,56 , and $62 \%$ for sprays applied every 7 , 10 , and 14 days, respectively. At the last assessment date in 1994, 95\% of the foliage in the untreated control plot exhibited symptoms of Septoria leaf spot and early blight. Chlorothalonil limited final foliar infection to $10.5,10.5,15.3$, and $21.8 \%$ for sprays applied at 7,10 , and 14 days and according to Tom-Cast, respectively. According to AUDPC data, all fungicide treatments significantly reduced foliar blight in comparison to the untreated control in 1993 to 1994 (Table 1). In 1993, the 7-day-interval treatment was more effective in managing foliar blight than the 10and 14-day-interval treatments. In 1994, chlorothalonil treatments' efficacy against foliar blight did not differ significantly.

In 1995 foliar blight caused by A. solani and $S$. lycopersici did not differ significantly between cultivars at either location. In MI, chlorothalonil applications limited

Table 1. The effect of foliar fungicide application on percentage of anthracnose fruit rot and area under the disease progress curve (AUDPC) in 1993 and 1994

\begin{tabular}{|c|c|c|c|c|c|c|c|c|}
\hline \multirow[b]{3}{*}{ Treatment $^{w}$} & \multicolumn{4}{|c|}{ Anthracnose fruit rot (\%) } & \multicolumn{4}{|c|}{ AUDPC (foliar blight $\times$ day) ${ }^{x}$} \\
\hline & \multicolumn{2}{|c|}{ Michigan } & \multicolumn{2}{|c|}{ Indiana } & \multicolumn{2}{|c|}{ Michigan } & \multicolumn{2}{|c|}{ Indiana } \\
\hline & $1993^{y}$ & 1994 & 1993 & 1994 & 1993 & 1994 & 1993 & 1994 \\
\hline 7 7-day & $9.2 \mathrm{a}^{\mathrm{z}}$ & $2.2 \mathrm{a}$ & $7.7 \mathrm{a}$ & $1.8 \mathrm{a}$ & $269.2 \mathrm{a}$ & $77.7 \mathrm{a}$ & $914.0 \mathrm{a}$ & $122.6 \mathrm{a}$ \\
\hline 10-day & $13.0 \mathrm{a}$ & $6.2 \mathrm{~b}$ & $10.5 \mathrm{a}$ & $2.5 \mathrm{a}$ & $249.3 \mathrm{a}$ & $93.7 \mathrm{a}$ & $1394.0 \mathrm{~b}$ & $138.9 \mathrm{a}$ \\
\hline 14-day & $18.0 \mathrm{a}$ & $9.5 \mathrm{c}$ & $24.3 \mathrm{~b}$ & $7.2 \mathrm{a}$ & $283.7 \mathrm{a}$ & $101.0 \mathrm{a}$ & $1433.0 \mathrm{~b}$ & $172.1 \mathrm{a}$ \\
\hline Tom-Cast & $18.0 \mathrm{a}$ & $9.8 \mathrm{c}$ & & $9.3 \mathrm{a}$ & $383.0 \mathrm{a}$ & $122.7 \mathrm{a}$ & & $166.1 \mathrm{a}$ \\
\hline Unsprayed control & $91.8 \mathrm{~b}$ & $30.7 \mathrm{~d}$ & $69.8 \mathrm{c}$ & $39.0 \mathrm{~b}$ & $1,154.0 \mathrm{~b}$ & $227.8 \mathrm{~b}$ & $2314.0 \mathrm{c}$ & $835.4 \mathrm{~b}$ \\
\hline
\end{tabular}

w In 1993 to 1994 (Michigan and Indiana), 8, 6, and 4 chlorothalonil sprays were applied for the 7-, 10-, and 14-day-interval treatments, respectively. TomCast advised 4 (Michigan) sprays in 1993, and 3 (Michigan) and 5 (Indiana) sprays in 1994.

${ }^{\mathrm{x}}$ Foliar blight caused by Alternaria solani, Phytophthora infestans, and/or Septoria lycopersici was assessed.

${ }^{y}$ Fruit rot caused by P. infestans and Colletotrichum coccodes.

${ }^{\mathrm{z}}$ Means within a column followed by the same letter are not significantly different according to Fisher's least significant difference $(P=0.05)$.

Table 2. The effect of foliar fungicide application on percentage of anthracnose fruit rot and area under the disease progress curve (AUDPC) for Ohio 7814 and 8245 tomatoes in 1995

\begin{tabular}{|c|c|c|c|c|c|c|c|c|}
\hline \multirow[b]{3}{*}{ Treatment $^{\mathrm{x}}$} & \multicolumn{4}{|c|}{ Anthracnose fruit rot (\%) } & \multicolumn{4}{|c|}{ AUDPC (foliar blight $\times$ day) } \\
\hline & \multicolumn{2}{|c|}{ Michigan } & \multicolumn{2}{|c|}{ Indiana } & \multicolumn{2}{|c|}{ Michigan } & \multicolumn{2}{|c|}{ Indiana } \\
\hline & 7814 & 8245 & 7814 & 8245 & 7814 & 8245 & 7814 & 8245 \\
\hline 7-day & $4.0 \mathrm{~b}^{\mathrm{z}}$ & $2.5 \mathrm{~b}$ & $3.0 \mathrm{~b}$ & $3.2 \mathrm{c}$ & $146.7 \mathrm{~b}$ & $188.5 \mathrm{~b}$ & $56.2 \mathrm{c}$ & $44.3 \mathrm{~b}$ \\
\hline 10-day & $3.3 \mathrm{~b}$ & $4.2 \mathrm{~b}$ & $4.1 \mathrm{~b}$ & $4.7 \mathrm{c}$ & $189.0 \mathrm{~b}$ & $204.2 \mathrm{~b}$ & $61.5 \mathrm{c}$ & $70.3 \mathrm{~b}$ \\
\hline 14-day & $9.7 \mathrm{~b}$ & $3.8 \mathrm{~b}$ & $11.3 \mathrm{~b}$ & $11.0 \mathrm{~b}$ & $376.8 \mathrm{a}$ & $217.5 \mathrm{~b}$ & $136.8 \mathrm{~b}$ & $65.4 \mathrm{~b}$ \\
\hline Tom-Cast & $3.0 \mathrm{~b}$ & $5.7 \mathrm{~b}$ & $5.3 \mathrm{~b}$ & $2.2 \mathrm{c}$ & $214.8 \mathrm{~b}$ & $190.7 \mathrm{~b}$ & $58.3 \mathrm{c}$ & $47.1 \mathrm{~b}$ \\
\hline Unsprayed Control & $43.2 \mathrm{a}$ & $37.0 \mathrm{a}$ & $26.0 \mathrm{a}$ & $18.8 \mathrm{a}$ & $406.8 \mathrm{a}$ & $433.2 \mathrm{a}$ & $427.6 \mathrm{a}$ & $361.3 \mathrm{a}$ \\
\hline
\end{tabular}

${ }^{\mathrm{x}}$ Tom-Cast advised 6 (Michigan) and 7 (Indiana) sprays in 1995. In 1995 10, 7, and 5 (Indiana) and 8, 6, and 4 (Michigan) chlorothalonil sprays were applied for the 7-, 10-, and 14-day-interval treatments, respectively.

y Foliar blight caused by Alternaria solani and/or Septoria lycopersici was assessed.

${ }^{\mathrm{z}}$ Means within a column followed by the same letter are not significantly different according to Fisher's least significant difference $(P=0.05)$. 
final foliar infection of Ohio 7814 to 8.3, $8.3,16.7$, and $12.5 \%$ for sprays applied every 7,10 , and 14 days and according to Tom-Cast, respectively, compared with the untreated control plot $(20.0 \%)$. In IN, the untreated control plot with Ohio 7814 exhibited $48.7 \%$ foliar blight at the last assessment date. Chlorothalonil applications limited final foliar infection to 4.8, 6.1, 19.4 , and $5.5 \%$ for sprays applied every 7 , 10, and 14 days and according to TomCast, respectively. Fungicide applications limited final foliar infection of Ohio 8245 to $8.3,10.0,10.0$, and $11.7 \%$ (MI) for sprays applied every 7,10 , and 14 days and according to Tom-Cast, respectively, compared with the untreated control plot $(18.8 \%)$. At the last assessment date, $46.8 \%$ (IN) of the foliage in the untreated control plot exhibited symptoms of Septoria leaf spot and early blight in Ohio 8245 . Chlorothalonil applications limited final foliar infection to 2.9, 6.9, 7.0, and 3.0\% for sprays applied every 7,10 , and 14 days and according to Tom-Cast, respectively. AUDPC data for Ohio 8245 and Ohio 7814 indicated that all fungicide treatments significantly limited foliar disease in comparison to the unsprayed control (MI and IN) (Table 2). With the exception of chlorothalonil applied every 14 days to Ohio 7814 (MI and IN), there was no significant difference in AUDPC values among regimens of chlorothalonil applications.

Economic benefit. In 1993 and 1994, chlorothalonil applied at 10-day intervals in IN resulted in the highest $\mathrm{BPH}$ and RPFD (\$17.33) because of reduced fungicide cost and acceptable AFR control.
However, in MI this application interval resulted in the greatest economic loss because of an FRP > 2.9\% and crop rejection (Table 3). In 1993 and 1994, the 7-dayinterval treatment resulted in an economically profitable crop and an RPFD (\$12.74) at both locations. Chlorothalonil applied according to the Tom-Cast program and at 14-day intervals resulted in FRP $>2.9 \%$, crop rejection, no RPFD, and high economic loss in 1993 and 1994 in both locations.

In 1995, the highest BPH and RPFD resulted from chlorothalonil applied every 14 days to Ohio 8245 (MI). However, this treatment resulted in FRP $>2.9 \%$ and crop rejection of Ohio 7814 (MI and IN) and Ohio 8245 (IN) (Table 4). Chlorothalonil applied according to the Tom-Cast program and at 10-day intervals resulted in an equal number of sprays. The BPH and RPFD were the same for these treatments with the exception of Ohio 8245 (MI) sprayed according to Tom-Cast, which exceeded the FRP (>2.9) allowed by processors.

\section{DISCUSSION}

The 7-day-interval is the minimum interval labeled for chlorothalonil application and is most commonly used. However, due to weather conditions unfavorable for spraying and scheduling conflicts, this interval may be lengthened to intervals as long as 14 days. Spray intervals for weather-based systems such as Tom-Cast vary according to environmental conditions; i.e., longer intervals will occur during periods that do not favor disease development. The Tom-Cast system has been

Table 3. Benefit per hectare (BPH) of foliar fungicide application schedules to control fungal fruit rots in tomato production valued at $\$ 5,025$ per hectare in 1993 and 1994

\begin{tabular}{|c|c|c|c|c|}
\hline \multirow[b]{3}{*}{ Treatment ${ }^{y}$} & \multicolumn{4}{|c|}{ ВPH (\$) } \\
\hline & \multicolumn{2}{|c|}{ Michigan } & \multicolumn{2}{|c|}{ Indiana } \\
\hline & 1993 & 1994 & 1993 & 1994 \\
\hline 7-day & $4,659.40$ & $4,659.40$ & $4,659.40$ & $4,659.40$ \\
\hline 10-day & $-5,299.20^{z}$ & $-5,299.20$ & $4,750.80$ & $4,750.80$ \\
\hline 14-day & $-5,207.80$ & $-5,207.80$ & $-5,253.50$ & $-5,207.80$ \\
\hline Tom-Cast & $-5,207.80$ & $-5,162.10$ & $\ldots$ & $-5,253.50$ \\
\hline
\end{tabular}

${ }^{y}$ In 1993 to 1994 (Michigan and Indiana), 8, 6, and 4 chlorothalonil sprays were applied for the 7-, 10-, and 14-day-interval treatments, respectively. Tom-Cast advised 4 (Michigan) sprays in 1993, and 3 (Michigan) and 5 (Indiana) sprays in 1994.

${ }^{\mathrm{z}}$ Negative values represent fungicide expenditure in addition to crop loss. used successfully in midwestern states and Ontario to reduce the number of fungicide applications (13). In our study, AFR in plots where chlorothalonil was applied according to the Tom-Cast program was significantly greater than that occurring in the 7-day-interval treatment in 1994 (MI) and exceeded the $2.9 \%$ FRP threshold established by the processors. In 1993 (MI) and 1994 (IN), the Tom-Cast-prompted and 7-day treatments were statistically similar in controlling fruit rot. However, economic analysis revealed that the 1993 (MI) and 1994 (IN) crops produced with the Tom-Cast treatment would have been rejected by processors because of FRP exceeding the $2.9 \%$ threshold. In 1995, Tom-Cast successfully limited AFR in all plots to a level statistically similar to the 7day treatment. The Ohio 8245 crop in MI, however, would have been rejected by processors because the FRP was greater than $2.9 \%$. In these scenarios, the grower suffers loss from fungicide expenditure in addition to crop loss. If the crop is rejected after harvesting, the grower may also have incurred additional costs including increased labor associated with a slower harvest rate and sorters on the harvester, transportation to the processor, and unloading and disposing of the rejected fruit. Additionally, continually receiving lower grades affects growers' season-long averages, which processors consider in determining future contracts with growers (S. Smith, Red Gold, Inc., personal communication).

Tom-Cast is based only on epidemiology of A. solani, although some researchers believe it is effective against other tomato pathogens (13,26). However, in our 1993 (MI) plots, Tom-Cast was not successful in limiting FRP to less than $2.9 \%$ when challenged by $P$. infestans, a pathogen that Tom-Cast was not developed to predict. Although $P$. infestans was the major fruitrotting organism in the 1993 (MI) plot, it has not caused economic problems in midwestern commercial tomato fields. However, late blight poses a threat to commercial tomato producers because of the close proximity of tomato and potato fields and the threat of introducing late blight inoculum via infected potato seed. Validation of the FAST system, from

Table 4. Benefit per hectare (BPH) and return per fungicide dollar (RPFD) of foliar fungicide application schedules to control fungal fruit rots in tomato production valued at $\$ 5,025$ per hectare for cultivars Ohio 7814 and 8245

\begin{tabular}{|c|c|c|c|c|c|c|c|c|}
\hline \multirow[b]{3}{*}{ Treatment $\mathbf{t}^{\mathrm{y}}$} & \multicolumn{4}{|c|}{ BPH (\$) } & \multicolumn{4}{|c|}{ RPFD (\$) } \\
\hline & \multicolumn{2}{|c|}{ Michigan } & \multicolumn{2}{|c|}{ Indiana } & \multicolumn{2}{|c|}{ Michigan } & \multicolumn{2}{|c|}{ Indiana } \\
\hline & Ohio 7814 & Ohio 8245 & Ohio 7814 & Ohio 8245 & Ohio 7814 & Ohio 8245 & Ohio 7814 & Ohio 8245 \\
\hline 7-day & $4,659.40$ & $4,659.40$ & $4,568.00$ & $4,568.00$ & 12.74 & 12.74 & 10.00 & 10.00 \\
\hline 10-day & $4,750.80$ & $4,750.80$ & $4,705.10$ & $4,705.10$ & 17.33 & 17.33 & 14.71 & 14.71 \\
\hline 14-day & $-5,207.80^{\mathrm{z}}$ & $4,842.20$ & $-5,253.50$ & $-5,253.50$ & 0.00 & 26.49 & 0.00 & 0.00 \\
\hline Tom-Cast & $4,750.80$ & $-5,299.20$ & $4,705.10$ & $4,705.10$ & 17.33 & 0.00 & 14.71 & 14.71 \\
\hline
\end{tabular}

y Tom-Cast advised 6 (Michigan) and 7 (Indiana) sprays in 1995. In 1995, 10, 7, and 5 (Indiana) and 8, 6, and 4 (Michigan) chlorothalonil sprays were applied for the 7-, 10-, and 14-day-interval treatments, respectively.

${ }^{\mathrm{z}}$ Negative values represent fungicide expenditure in addition to crop loss. 
which Tom-Cast was derived, determined that while the FAST system results in early blight control statistically similar to that obtained with more frequent sprays, in certain years it may not protect against fruit-rotting organisms (24). Therefore, the FAST system currently used in Pennsylvania includes a component that advises switching to a weekly fungicide spray schedule once pink fruit are present in the field (13).

Although Tom-Cast was not consistent in producing a positive $\mathrm{BPH}$, commercial use of Tom-Cast in the Midwest has not resulted in crop rejection because of AFR. Growers using the Tom-Cast system may use a more conservative DSV to trigger fungicide sprays than the threshold used in this and other studies (18). Rotation practices typically followed by growers may help limit initial disease inoculum. When Louws et al. (19) relied on natural inoculum to evaluate Tom-Cast in fields with no recent history of tomato production, disease levels increased each year of the 3year study. In some cases, treatment rows in our experimental field plots were inoculated with $C$. coccodes, and some plots were established in fields with a long history of tomato production with inadequate rotation, possibly exposing plants to unusually severe disease pressure, evidenced by the occasional high AFR in the most stringent (7-day) fungicide program. However, to compensate for the high incidence of AFR in plots, our economic analysis was more liberal than that of the industry because we used FRP (total fruit rot above that observed in the 7-day-interval treatment plot) rather than percentage of AFR to calculate BPH and RPFD.

Growers using Tom-Cast to schedule fungicide applications should be aware of the system's limitations in controlling AFR and be prepared to make additional fungicide applications when environmental conditions conducive to disease or significant disease pressure from pathogens not included in the model occur. Efficacy of Tom-Cast against AFR may be greater in other geographical areas where weather conditions are less conducive to the fruitrotting organisms, or in fresh market tomato production because fruit are harvested while still green (36). Brammall (3) reported that fungicides used according to the tomato forecasting system FAST were not required to ensure marketable yield of commercial fresh tomato cultivars in Ontario.

A range of AFR resistance exists among commercial processing tomato varieties (9-12). Although genetic resistance alone is insufficient to manage AFR, cultivars with some degree of resistance may require fewer fungicide sprays to achieve acceptable levels of disease control (9-12). Gleason et al. (13) suggested that resistance indices for tomato cultivars should be used to adjust prescriptive Tom-Cast-based fungicide application intervals to maximize fungicide use. In this study, using the cultivar resistant to AFR (Ohio 8245) did not reduce AFR compared with using a susceptible control. In contrast, when Fulling et al. (12) estimated the number of integrated Tom-Cast-based fungicide sprays required with anthracnose-tolerant cultivars such as Ohio 8245, they concluded that a more liberal DSV could be used, resulting in three to four fewer fungicide applications compared with that used for susceptible cultivars. However, Fulling et al. (12) used a higher acceptable AFR incidence $(13.5 \%)$ than that used in this study $(2.9 \%)$. In our study, fruit were harvested when at least $75 \%$ were fully ripe and thereby susceptible to infection and development of AFR. Because of uneven ripening of the late-maturing Ohio 8245 fruit in IN and MI, a portion of the fruit may have been riper at harvest and evaluation than those in Fulling's study (12), thus masking the AFR resistance expected with this cultivar.

Foliar blight was controlled by all chlorothalonil application programs compared with the unsprayed control. In 1993 and 1994, all treatment regimens were equally effective in limiting foliar blight; the Tom-Cast treatment reduced the number of sprays by as much as $62 \%$ compared with the 7-day-interval treatment. An exception occurred in 1993 in IN when Septoria leaf blight became established early in the season and the 7-day-interval treatment provided significantly greater control than the other treatments. Although Louws et al. (19) determined that defoliation caused by early blight has little impact on fruit mold incidence and no relationship to yield, growers typically are concerned by foliar blight. The progression of foliar blight is an indication that inoculum is present and environmental conditions have been conducive to infection.

Midwestern growers of processing tomatoes rely on repeated applications of protective fungicides to limit AFR, the most commonly occurring fruit rot, and thereby produce profitable crops. Cost and efficacy vary among the three fungicides (chlorothalonil, mancozeb, and fixed copper) currently registered for use on tomatoes against AFR. Mancozeb products remain registered but have not been used in recent years because of processors' refusal to purchase raw tomato products treated with EBDC fungicides. Until recently, growers could use captafol, anilazine, or both for protection against AFR. However, the captafol registration was canceled in the late 1980s, and the manufacturer of anilazine announced a voluntary withdrawal of its registration in 1992 (23). Various fixed copper products (copper hydroxide, copper sulfates, copper resinate) are used, especially early in the season, for control of bacterial diseases and are marginally effective against fungal diseases $(15,32,33)$. The 1992 IN tomato grower/processor survey showed that chlorothalonil was the preferred fungicide (7).

Based on data from this study, growing processing tomatoes in MI and IN without chlorothalonil to protect against AFR is not commercially feasible. Unsprayed control plots yielded a range of only 8.2 to $81.2 \%$ healthy fruit. Without any chlorothalonil applications, one can expect a processing tomato crop failure caused by AFR, whereas an inadequate spray program can result in significant AFR and financial loss despite expenditures on fungicides. In general, if disease pressure is light, then reducing the number of sprays does not pose a significant risk to crop quality and the RPFD is relatively high. However, under severe disease pressure, reduced protection resulting from a reduced number of sprays may result in rejection of the crop at the processing site. Additional research is needed to incorporate epidemiological aspects of $C$. coccodes into Tom-Cast to make it a more inclusive forecaster $(4,13)$.

\section{ACKNOWLEDGMENTS}

This research was supported in part by the North Central Region Pesticide Impact Assessment Program and the National Agricultural Pesticide Impact Assessment Program (NAPIAP) of the United States Department of Agriculture.

\section{LITERATURE CITED}

1. Barksdale, T. H., and Stoner, A. K. 1981. Levels of tomato anthracnose resistance measured by reduction of fungicide use. Plant Dis. 65:71-72.

2. Basu, P. K. 1974. Measuring early blight, its progress and influence on fruit losses in nine tomato cultivars. Can. Plant Dis. Survey 54:45-51.

3. Brammall, R. A. 1993. Effect of foliar fungicide treatment on early blight and yield of fresh market tomato in Ontario. Plant Dis. 77:484-488.

4. Byrne, J. M. 1996. Epidemiology and Management of Colletotrichum coccodes on Processing Tomatoes. M.S. thesis. Michigan State University, East Lansing.

5. Dillard, H. R. 1988. Influence of temperature, $\mathrm{pH}$, osmotic potential and fungicide sensitivity on germination of conidia and growth from sclerotia of Colletotrichum coccodes in vitro. Phytopathology 78:1357-1361.

6. Dillard, H. R. 1992. Colletotrichum coccodes: The pathogen and its hosts. Pages 225-236 in: Colletotrichum: Biology, Pathology and Control. J. A. Bailey and M. J. Jerger, eds. Br. Soc. Plant Pathol. CAB International, Oxon.

7. Foster, R. E., Latin, R. X., and Weller, S. C. 1992. Pesticide use on processing tomatoes grown in Indiana. Purdue Univ. Coop. Ext. Serv. Bull. ID-193.

8. Fulling, B. A., Latin, R. X., and Tigchelaar, E. C. 1993. Evaluation of fungicide application schedules for control of anthracnose of tomato, 1992. Fungic. Nematicide Tests 48:190.

9. Fulling, B. A., Tigchelaar, E. C., and Latin, R. X. 1992. Integration of resistance with a weather-based fungicide scheduling program for control of anthracnose on processing tomatoes. (Abstr.) Phytopathology 82:991.

10. Fulling, B. A., Tigchelaar, E. C., and Latin, R. X. 1993. Resistance of tomato genotypes to anthracnose and foliar diseases. Biol. Cult. Test 8:57. 
11. Fulling, B. A., Tigchelaar, E. C., and Latin, R. X. 1993. Response of tomato cultivars to two fruit inoculation procedures with Colletotrichum coccodes at different stages of fruit maturity. (Abstr.) Phytopathology 83:1389.

12. Fulling, B. A., Tigchelaar, E. C., and Latin, R. 1995. Integration of host resistance and weather-based fungicide scheduling for control of anthracnose of tomato fruit. Plant Dis. 79:228-233

13. Gleason, M. L., MacNab, A. A., Pitblado, R. E., Ricker, M. D., East, D. A., and Latin, R. X. 1995. Disease-warning systems for processing tomatoes in eastern North America: Are we there yet? Plant Dis. 79:113-121.

14. Gould, W. A. 1983. Tomato Production, Processing, and Quality Evaluation. 2nd ed. AVI Publishing Company, Westport, CT.

15. Hausbeck, M. K. 1995. Control of diseases of processing tomatoes with foliar sprays, 1994. Fungic. Nematicide Tests 50:168-169.

16. Johnston, S. A., Hamilton, G. C., and Phillips, J. R. 1994. Assessment of fungicide benefits for the control of anthracnose in processing tomatoes, 1993. Fungic. Nematicide Tests 49:163.

17. Jones, J. B., Jones, J. P., Stall, R. E., and Zitter, T. A. 1991. Compendium of Tomato Diseases. American Phytopathological Society, St. Paul, MN.

18. Louws, F. J. 1994. Integrated Disease Management in Tomato Production Systems. Ph.D. diss. Michigan State University, East Lansing.

19. Louws, F. J., Hausbeck, M. K., Kelly, J. F., and Stephens, C. T. 1996. Impact of reduced fungicide and tillage on foliar blight, fruit rot, and yield of processing tomatoes. Plant Dis. 80:1251-1256

20. MacNab, A. A., Pennypacker, S. P., and Barksdale, T. H. 1989. Tomato early blight and fruit rot levels influenced by variety and fungicide treatments, 1988. Biol. Cult. Tests 4:29.

21. Madden, L. V., Pennypacker, S. P., and MacNab, A. A. 1978. FAST, a forecast system for Alternaria solani on tomato. Phytopathology 68:1354-1358.

22. Michigan Agricultural Experiment Station. 1995. The assessment of pesticides at risk in the future of Michigan food and feed plant agriculture: A process. Mich. Agric. Exp. Stn., Spec. Rep. 86.

23. National Academy Press. 1987. Estimates of Dietary Oncogenic Risk. Pages 45-99 in: Regulating Pesticides in Food, The Delaney Paradox. Carla Carlson, ed. Committee on Scientific and Regulatory Issues Underlying Pesticide Use Patterns and Agricultural Innovation. Board on Agriculture, National Research Council, National Academy Press, Washington, DC

24. Pennypacker, S. P., Madden, L. V., and Mac$\mathrm{Nab}$, A. A. 1983. Validation of an early blight forecasting system for tomatoes. Plant Dis. 67:287-289.

25. Pitblado, R. E. 1988. Development of a weather-timed fungicide spray program for field tomatoes. (Abstr.) Can. J. Plant Pathol. 10:371.

26. Pitblado, R. E. 1992. Development and implementation of Tom-Cast. Ont. Minist. Agric. Food Publ. p. 18.

27. Poysa, V., Brammall, R. A., and Pitblado, R.
E. 1993. Effects of foliar fungicide sprays on disease and yield of processing tomatoes in Ontario. Can. J. Plant Sci. 73:1209-1215.

28. Precheur, R. J., Bennett, M. A., Riedel, R. M. Wiese, K. L., and Dudek, J. 1992. Management of fungicide residues on processing tomatoes. Plant Dis. 76:700-702.

29. Purdue University Cooperative Extension Service. 1995. Midwest Vegetable Production Guide for Commercial Growers. Purdue Univ. Coop. Ext. Serv., West Lafayette, IN.

30. Shaner, G., and Finney, R. E. 1977. The effect of nitrogen fertilization on the expression of slow-mildewing resistance in Knox wheat. Phytopathology 67:1051-1056.

31. Sherf, A. F., and MacNab, A. A. 1986. Vegetable Diseases and Their Control. 2nd ed. John Wiley \& Sons, NY.

32. Shoemaker, P. B. 1994. Fungicide evaluation for tomato early blight, 1993. Fungic. Nematicide Tests 49:171.

33. Shoemaker, P. B. 1995. Fungicide evaluation for tomato foliar diseases II, 1994. Fungic. Nematicide Tests 50:180.

34. Stevenson, W. R., Evans, G. E., and Barksdale, T. H. 1978. Evaluation of tomato breeding lines for resistance to fruit anthracnose. Plant Dis. Rep. 62:937-940.

35. United States Department of Agriculture. 1996. Agriculture Statistics. U.S. Dep. Agric., U.S. Government Printing Office, Washington, DC.

36. Williamson, J. W., and Hilty, J. W. 1988. Comparison of a forecast generated system and a weekly spray regimen for early blight control in trellised tomatoes. Tenn. Farm Home Sci. 146:8-12. 